\title{
Verdades verdadeiras: um dicionário de humor e crítica da sociedade na imprensa oitocentista portuguesa
}

\begin{abstract}
Palavras-chave:
Imprensa Oitocentista

Humor

Crítica Social e Política
\end{abstract}

Keywords:

Nineteenth-century Press

Humour

Social and Political Criticism
Álvaro Antonio Klafke*

\begin{abstract}
Resumo: $\mathrm{O}$ artigo analisa o Dicionário das verdades verdadeiras, publicado em forma de verbetes no periódico português $O$ Artilheiro (Porto, 1835-1837) durante o ano de 1836. Esse "dicionário" era fundamentalmente humorístico, apelando continuamente para a ironia, a sátira e o sarcasmo. Através da seleção e da observação de alguns termos, objetiva-se compor um mosaico de uma variedade de temas, o qual permite refletir sobre a maneira pela qual um órgão de imprensa utilizava-se de recursos retóricos extremamente criativos, e possivelmente de razoável apelo popular, para estabelecer sua crítica da sociedade e da política do período.
\end{abstract}

Abstract: The article analyzes the Dicionário das verdades verdadeiras (Dictionary of True Truths), published in the form of entries in the Portuguese periodical O Artilheiro (Porto, 1835-1837) during the year 1836. This "dictionary" was fundamentally humoristic, appealing continuously to irony, satire and sarcasm. Through the selection and observation of some words, the goal is to compose a set of a variety of themes, which allows us to think about the way by which a newspaper used very creative rhetorical means, and likely of sensible popular appeal, to set up his critique of society and politics of the period.

Recebido em 03 de março de 2017. Aprovado em 02 de agosto de 2017.

\section{Introdução}

Entre 22 de agosto de 1835 e 14 de julho de 1837 circulou na cidade do Porto (Portugal) um diário intitulado $O$ Artilheiro. Quanto aos aspectos materiais, era similar a muitos daquele rico período da imprensa portuguesa. ${ }^{1}$ Politicamente, podese defini-lo como liberal moderado, defendendo a moralidade e a transparência nos governos, porém sem grandes alterações sociais. $\mathrm{O}$ que o distinguia da maioria - sem que isso configurasse uma característica exclusiva - era o tom permanentemente jocoso, utilizando ao máximo dos recursos do humor, da sátira, da ironia e do sarcasmo para sustentar sua argumentação. Esse periódico, no ano de 1836, iniciou a publicação, que perdurou por várias edições, de um curioso "dicionário", intitulado de Verdades verdadeiras. Tal léxico, cujos verbetes receberiam definições cômicas e críticas, compõe um conjunto apreciável de comentários sub-reptícios (ou nem tanto) acerca da vida social e cultural de então.

Este artigo tem por objetivo analisar o conjunto do "dicionário" de O Artilheiro, selecionando alguns termos para compor um mosaico que permita observar a forma como um órgão de imprensa utilizava-se de recursos retóricos extremamente criativos, e possivelmente de razoável apelo popular, para estabelecer sua crítica da sociedade e da política. A variedade dos assuntos abordados pelo jornal atesta sua pretensão de fazer rir, mas de um modo que também causasse aquele desconforto que forçava o leitor à reflexão, especialmente na direção do questionamento pretendido a respeito de vários aspectos da sociedade portuguesa daqueles anos conturbados. ${ }^{2}$

Há um bom tempo que a historiografia, tanto a estrangeira quanto a do Brasil, reconhece a relevância dos estudos que se valem da imprensa, tomada como fonte e/ou objeto de reflexão

\footnotetext{
* Doutor em História pela Universidade Federal do Rio Grande do Sul (UFRGS). Analista Pesquisador em História - Fundação de Economia e Estatística (FEE). E-mail: klafkealvaro@gmail.com.
} 
sobre inúmeros assuntos e temporalidades. Este reconhecimento foi acompanhado de uma consistente elaboração teórica acerca de sua abordagem, desfazendo algumas ingenuidades e simplismos propiciados por aproximações um tanto rápidas. Seguindo uma oportuna e já bastante citada lembrança de Robert Darnton (1996, p. 15), a imprensa - e aqui referimo-nos à imprensa periódica - deve ser analisada a partir de sua posição como agente, mais do que simples "caixa de ressonância” social. Sua ação, sem dúvida, se dá por meio do uso criativo da língua, estabelecendo pontes de comunicação que viabilizam suas intenções informativas, pedagógicas, propagandísticas, de condicionamento ideológico, enfim, de várias ordens. Cabe-nos, em que pese a distância cultural estabelecida pelo tempo e pelo espaço, buscar uma aproximação ao entendimento desses mecanismos e ferramentas linguísticas. Com vistas a esse objetivo, a leitura do dicionário aqui apresentado será orientada por uma concepção teórica híbrida - e existem as puras, ou isoladas? Para além das considerações concernentes a questões referentes ao humor, que surgirão entre os abundantes exemplos do periódico, a análise também se inspira numa mescla do contextualismo linguístico com a história dos conceitos, aqui pensados, ambos, de uma forma bastante livre. Do primeiro, importa a consideração do compartilhamento linguístico da comunidade de sujeitos (POCOCK, 2003), da segunda, destacase a relação estabelecida entre a época - que abrange o período de $O$ Artilheiro -, e a modificação histórica de certos conceitos e noções fundamentais (KOSELLECK, 2006), além da lembrança da função do conceito como fator de mudanças, para além de mero indicador destas (KOSELLECK, 1992).

Trata-se, portanto, de destacar o uso criativo da Língua Portuguesa, enquanto estratégia de abordagem de um público que se pretendia ampliar, embora sem abdicar do potencial de crítica, essencial naquele período de intensas disputas, em Portugal e em grande parte do mundo ocidental.

Para efeito de organização, propõese uma divisão em tópicos temáticos, embora algumas definições de termos, evidentemente, abrangessem diversos aspectos. Assim, as seções que seguem - imprensa, humor e crítica cultural; misantropia e misoginia; Igreja e religião; política e sociedade - buscam destacar e reunir elementos comuns aos verbetes, e a última, de considerações finais, elenca algumas reflexões que objetivam analisar conjuntamente elementos importantes da divulgação do "dicionário".

\section{Imprensa, humor e crítica cultural}

A maneira pela qual o periódico anunciou, na edição $n^{\circ} 7$, de 11 de janeiro de 1836, o início da publicação de seu dicionário ${ }^{3}$, revestida de irônica pompa, já demonstrava seus objetivos humorísticos:

[O Artilheiro] Lê, e guarda quanto escolhe como mais útil. No livro do célebre Compadre, de que os seus leitores já têm acreditado conhecimento, encontra-se um Dicionário que ele intitulou de Verdades verdadeiras, o qual encerra objetos de jovial e decente entretenimento. $\mathrm{O}$ Artilheiro agenciou algumas Obras em que no mesmo estilo se encontram finíssimos pensamentos, e como Edição correta e acrescentada, o vai apresentar à vergonha do mundo! (O ARTILHEIRO, 1836a) $)^{4}$.

A partir desse anúncio, e recorrendo bastante à autoironia, o jornal buscaria divertir, romper um estado de seriedade tacanha - e implicitamente falsa -, fazer rir, enfim. Contudo, esse riso, catártico, nervoso ou envergonhado, deveria estar a serviço da reflexão e da polêmica política, que marcava o caráter fundamental dos textos da imprensa de então. Como sublinha Isabel Lustosa. (2000, p. 427), nenhum dos jornais daquele período surgiu com o objetivo exclusivo de fazer humor. O humor brotava da polêmica, quando se esgotava o estoque de argumentos. Era uma de suas armas, ao lado da agressão verbal pura e simples.

Entretanto, talvez não se trate propriamente de esgotamento do estoque de argumentos, pois o 
recurso de fórmulas humorísticas poderia embasar uma argumentação bastante sólida, como veremos através de inúmeros exemplos. Foi através da utilização recorrente de diversos instrumentos retóricos ligados ao humor, como a sátira, a ironia, $\mathrm{o}$ sarcasmo, que o redator de $O$ Artilheiro (supondo-se que fosse obra de uma só pessoa) deixou registrada sua concepção de mundo e sociedade e sua intenção de nela interferir, da mesma forma que outros articulistas o faziam de modo pretensamente mais "sério". Nesse sentido, recorrendo a uma referência já bastante utilizada, não parece demais observar, com Bergson, que o ambiente natural do riso é a sociedade, e para compreender aquele é necessário investigar esta, porque "[...] impõe-se sobretudo determinar-lhe a função útil, que é uma função social. "[...] O riso deve corresponder a certas exigências da vida em comum. $\mathrm{O}$ riso deve ter uma significação social” (BERGSON, [s. d.], p. 14).

$\mathrm{Na}$ defesa de seus métodos, o jornal portuense publicava, na edição no ${ }^{\circ} 135$, de 23 de junho de 1836, incorporada ao seu singular "dicionário", uma curiosa definição do vocábulo "Gravidade": "Seriedade, severidade: os Burros paneleiros são os animais, que mostram mais gravidade no seu aspecto" (O ARTILHEIRO, 1836x). No mesmo sentido, o próprio verbete "Seriedade" seria aquele atributo "que os Asnos possuem em grau superior", conforme a edição no 264 , de 29 de novembro de 1836 (O ARTILHEIRO, 1836ae). Rir seria uma capacidade fundamentalmente humana: "Riso: Movimento de complacência próprio do homem; e dele carecem todos os Brutos; portanto, o rir moderado, é de homem; o rir afetado, de Macacos; o rir às gargalhadas, de tolo: o nunca rir, é de Brutos" (O ARTILHEIRO, 1836ae). Para além de seus efeitos de libertação, o humor poderia ter uma função educativa, ou mesmo corretiva: "Sátira: Causa comichão, mas às vezes cura!” (O ARTILHEIRO, 1836ae).

Naquele período, os jornais viam-se em uma encruzilhada de modificações, de ordem cultural, no status que o riso e o risível assumiam no contexto da modernidade. Apoiando-se, entre outros autores, sobretudo em Schopenhauer, Verena Alberti (1999, p. 196-197) demonstra a legitimação do ato de rir frente ao pensamento considerado sério:
Essa mudança representada pela teoria de Schopenhauer pode nos ajudar a compreender o que se passou na relação entre o riso e o pensamento. De modo esquemático, pode-se dizer que, para as teorias clássicas, o sério e a gravidade coincidem com a verdade, de modo que o não-sério $[s i c]$ (o espaço do riso) é o não-verdadeiro $[s i c]$.

$\mathrm{Na}$ abordagem moderna, o sério e a gravidade não coincidem mais com a verdade; o riso continua ser o não-sério [sic], mas isso, agora, é positivo, porque significa que ele pode ir para além do sério e atingir uma realidade "mais real" do que o pensado. $\mathrm{O}$ não-sério [sic] passa a ser mais "verdadeiro" que o sério, fazendo com que a significação do riso se torne "mais fundamental".

Assim, ridicularizar a seriedade e a circunspecção, tarefa empreendida por redatores que se travestiam de humoristas, não os tornava menos "verdadeiros" ou menos temíveis.

O significado crítico do riso que buscava provocar o jornal ficava evidente pela maneira como ele avaliava a própria atividade jornalística, dessacralizada em vários verbetes, por exemplo, na edição $n^{\circ}$ 7: "Abortar: no idioma das Imprensas, vale o mesmo que produzir" (O ARTILHEIRO, 1836a); na edição no 247, de 9 de novembro de 1836: "Periódicos: Saraivada, que cai de tempos em tempos, com redemoinho de vento" ( $\mathrm{O}$ ARTILHEIRO, 1836ac). Quantos significados poderia conter a singela palavra "pena"? Ademais, a edição no 246 , de 8 de novembro de 1836, cita: "Pena: Na cabeça, é adorno; no coração, angústia; na mão do Juiz, medo; na do escritor, história; na do Escrivão, perigo; na do Negociante, cautela; na dos namorados, baba; na dos aventureiros, calote; na dos Gazeteiros, mentira; e na dos cavilosos, destruição" (O ARTILHEIRO, 1836ab). Poucos deles, ao que parece, seriam de sentido positivo. Importa destacar o que se refere aos "gazeteiros", isto é, aos fautores da profusão de gazetas que circulavam no período, tidos sumariamente como mentirosos - sem qualquer menção de autoexclusão.

O deboche que alvejava a própria atividade jornalística também atingia a cultura em geral. Por exemplo, a edição $n^{\circ}$ 8, de 12 de janeiro de 
1836, assim definia: "Aleijar: na Literatura, vale o mesmo que $=$ traduzir" $($ O ARTILHEIRO, 1836b $)$. E a definição de "Autor: Nome que se dá a quem arremeda uma Obra com retalhos velhos: aliás não haveria tantos autores, visto que não aparece cousa nova" aparece na edição $\mathrm{n}^{\circ} 11$, de 15 de janeiro de 1836 (O ARTILHEIRO, 1836d). Um vocábulo similar, citado na edição no 92 , em 27 de abril de 1836, tampouco seria muito valorizado: "Escritor: tem havido ocasiões, em que este substantivo tem sido Sinônimo de Copista, Adulador, Maldizente, Velhaco, e até de Periodiqueiro" (O ARTILHEIRO, 18360). Nota-se novamente, na edição no 16, de 21 de janeiro de 1836, a autoironia com a imprensa, pela menção do fato de que "até" os "periodiqueiros" podiam ser vistos ou serem considerados como escritores. Coerentemente, um conjunto de escritos de vários tipos não seria muito valorizado: "Biblioteca: Fruta como a alcachofra: muita folha inútil, e pouco que aproveitar" (O ARTILHEIRO, 1836f). Tal opinião seria reforçada na definição de um verbete que significaria a ausência absoluta, nada. A definição "Nada: Cousa que só se pode ver escrita; e, portanto é necessário procurá-la nas Bibliotecas, onde se acham em grossos volumes. $\$$ Por nada: razão de Mulheres" foi citada em 5 de setembro de 1836, na edição no 193 (O ARTILHEIRO, 1836z). À crítica de ordem cultural, somava-se, neste caso, a misoginia, que merecerá uma abordagem específica no seguimento do texto.

A avaliação da cultura avançava sobre temas filosóficos, oportunidade para o redator escarnecer do pedantismo e da hipocrisia que julgava perceber em certas manifestações do pensamento. Por exemplo, na definição de escolástico: "Escolástico: Da escola... E mais nada” (O ARTILHEIRO, 18360). Além disso, a própria estrutura do raciocínio lógico era ironizada: "Axioma: Cada um chama assim a sua Opinião" (O ARTILHEIRO, 1836e). No mesmo sentido, o que seria um "Absurdo: é tudo aquilo que os nossos Antagonistas avançam contra a nossa opinião, ou além da nossa compreensão" ( $\mathrm{O}$ ARTILHEIRO, 1836a).

Alguns verbetes desse tópico chamam a atenção pela riqueza com que conseguem sintetizar uma ideia básica, para além do efeito cômico. É o caso de "Eternidade: Assombro da imaginação!!! Quem pensa nela sem horror?", verbete mencionado na edição $\mathrm{n}^{\circ} 112$, de 25 de maio de 1836 (O ARTILHEIRO, 1836q). Ou a fórmula graciosa que define "experiência", na edição no 116 , de 30 de maio de 1836: "Experiência: É a ignorância apalpando, como quem busca um caminho às escuras" (O ARTILHEIRO, 1836r). Mas a síntese que melhor define a concepção pouco lisonjeira do homem, na visão da edição no 125 de $O$ Artilheiro, de 11 de junho de 1836, está contida no significado atribuído ao termo filosofia. "Filosofia: O amor, e a prática da verdade. Vejam lá se será rara!" (O ARTILHEIRO, 1836t). A partir dessa visão, haveria outro conjunto de palavras que reforçariam a negatividade explícita, misantropa e misógina, recorrente na sua argumentação, que os efeitos humorísticos, ao contrário de suavizar, quase que realçavam.

\section{Misantropia e misoginia}

A opinião muito pouco benévola a respeito do ser humano ficava clara no verbete publicado em 25 de junho de 1836, na edição no 136 de $O$ Artilheiro, que caracterizava a espécie:

\section{Homem: O Bichinho mais manhoso, mais inconsequente, e mais incompreensível de quantos sustenta a terra, e o que mais abusa dos privilégios, que obteve do seu Criador. $\$$ Homem de bem: aquele que é do nosso partido. Homem feliz neste mundo: aquele, que tem alguma cousa de tolo, e pouco de honrado; porque só assim é que pode evitar o remorso. (O ARTILHEIRO, 1836y).}

Diante de tal concepção, logicamente que uma reunião ampliada desses seres tampouco redundaria em qualquer conjunto positivo. Portanto, a edição no 35, de 15 de fevereiro de 1836, assim define: "Comunidade: Certo número de Pessoas, que se ajuntam sem se conhecerem, vivem sem se amarem, e morrem sem se condoerem" (O ARTILHEIRO, 1836j). Contudo, havia o reconhecimento, sempre em tom sarcástico, de 
que era impossível, para a espécie humana, viver de outra forma que não fosse em comunidade. $\mathrm{E}$ isso era promovido pela significação criativa de um vocábulo simples, como o citado na edição $\mathrm{n}^{\circ}$ 23, de 30 de janeiro de 1836: "Cabana: Habitação rústica, que os Poetas, e os Filósofos gabam muito, porém nunca por ela deixam as Cidades" (O ARTILHEIRO, 1836g).

Como se vê, o recurso de buscar palavras simples, que em uma primeira aproximação teriam definições também singelas, mas que na pena do redator adquiriam sentidos ou prestavam-se a funções surpreendentes, era largamente utilizado. Ainda para reafirmar sua baixa consideração com a espécie humana, a definição de "pasto" constitui mais um bom exemplo. "Pasto: É o alimento do gado, e o lugar, onde anda a pastar: logo a denominação de casa de Pasto é expressiva quanto pode ser!" (O ARTILHEIRO, 1836z).

A visão negativa, que em alguns momentos parece bastante ingênua, repercutindo lugarescomuns, na verdade podia ser bastante perspicaz e sutil, como quando o redator demonstrava que a felicidade ou o infortúnio; no final das contas, dependeria de como a sociedade considerasse e de como o próprio indivíduo se visse. É o que transparece no significado de aventureiro: "Aventureiro: Homem louvável, quando é feliz, e punível, quando é infeliz" (O ARTILHEIRO, 1836e).

Se já foi demonstrado o conceito desfavorável em que era tido o ser humano em geral, cabe menção, pelo destaque que tinha no jornal (mesmo fora do âmbito restrito do dicionário) a péssima opinião acerca das mulheres em particular. Sua misoginia transparecia em muitos momentos. Veja-se, segundo a edição $\mathrm{n}^{\circ} 132$, de 20 de junho de 1836, o que seria uma "[...] Fúria": "Suponho que seria alguma mulher zelosa, ou desprezada, ou irada; de todos os modos ela sempre era mulher" (O ARTILHEIRO, 1836v). A figura mitológica servia para caracterizar, negativamente, na edição n ${ }^{\circ} 117$, de 31 de maio de 1836, as mulheres reais em geral. Havia, como corolário, uma excessiva idealização: "Fada: Mulher, que dava, e não pedia. Isso acabou já!” (O ARTILHEIRO, 1936s). Diante de tal postura, o significado do verbo "casar" era inequívoco na edição no 26, de 4 de fevereiro de 1836: "O mesmo que = Lá o vereis” (O ARTILHEIRO, 1836h).

O casamento, aliás, era uma das instituições que poderia estar em perigo, pelo menos nos moldes tradicionais, a depreender-se da definição de "amazona", mulher que não corresponderia a um ideal de esposa típica: "Amazona: Mulher, que não cuida em cozinhar, nem coser, nem remendar a roupa do Marido, e mais dos filhos" (O ARTILHEIRO, 1836b). A visão crítica em relação ao matrimônio era reforçada em outros momentos, como na picaresca caracterização de um celibatário, na edição no 27 , em 5 de fevereiro de 1836: "Celibatário: Homem, que não sustenta mulher, nem filhos" (O ARTILHEIRO, 1836i). Portanto, eventos como o falecimento do cônjuge, o qual foi citado na edição $\mathrm{n}^{\circ}$ 87, em 21 de abril de 1836, traria consequências cuja avaliação seria circunstancial, jamais absoluta: "Enviuvar: Problema, que para uns anuncia felicidade, e para outros desgraça. Isto prova, que as circunstâncias são as que determinam a essência das cousas" (O ARTILHEIRO, 1836n).

De qualquer forma, o problema estaria na mulher. Em nova aproximação à mitologia, o jornal publicava sua definição das Eumênides, revelando uma erudição que, por si só, já constituía um recurso retórico, ainda que o próprio periódico o ridicularizasse. "Eumênides: As Fúrias do Inferno. Os que por lá tem andado, dizem que são uma Sogra, e duas Cunhadas" (O ARTILHEIRO, 1836q).

A opinião negativa acerca das mulheres em particular, e do ser humano em geral, pode ser vista como excessivamente pessimista, notadamente para quem se arvorava em reformador social, em muitos momentos. E talvez isso não fosse negado pelo próprio redator. Para encerrar o tópico, a edição ${ }^{\circ}$ 211, de 27 de setembro de 1836, mostra um exemplo por meio do qual retornamos à filosofia e seus temas, destacando o seu desdém para com o pensamento otimista: "Otimismo: Um dos muitos disparates filosóficos, que só serve para enfeitar entes de razão" (O ARTILHEIRO, 1836aa). O estado de coisas que embasava uma visão de mundo desse tipo era relacionado com a decadência de outra instituição importantíssima, promotora de valores e hábitos: a 
Igreja, o que também merecia críticas, compondo um distinto conjunto de verbetes interessantes.

\section{Igreja e religião}

O periódico, nas partes "sérias" de sua trajetória, argumentava de forma bastante moderada, tangenciando o conservadorismo. Nesses momentos, ele acabava reforçando o papel da religião na formação e no autocontrole das pessoas. Entretanto, no dicionário era extremamente mordaz na abordagem do tema. Tanto a religião em si quanto os clérigos eram ridicularizados. Analogamente ao que acontecia em relação à função da mulher, especialmente frente ao casamento, satirizar ritos e padres, forma de humor bastante antiga, não escondia uma de suas funções principais: revelar um estado de coisas decadente que se contrapunha a um período idealizado, tido como áureo, respeitável, mas que se perdera.

Sua ironia, apresentada na edição $\mathrm{n}^{\circ}$ 257, de 21 de novembro de 1836, era implacável: "Religião: Ir à missa do meio-dia escolhendo a Igreja mais fachonível; ostentar sempre em pé de que não se faz senão por formalidade; e comungar no meio do maior barulho em Quinta-feira Santa" (O ARTILHEIRO, 1836ad). Contudo, a crítica não se limitava a um afrouxamento dos costumes e à falta de verdadeira fé dos seguidores. De certa forma, não poderia ser de outra maneira, pois a sua opinião sobre as lideranças religiosas tampouco era benévola. Definição de "Episcopado": "É o poder, a pompa, e a vaidade dos que juram renunciar a estas três cousas" (O ARTILHEIRO, 1836n).

Se a alta hierarquia da Igreja era contemplada com tal visão, obviamente que os demais estratos não estariam livres da zombaria, e nesses casos, como nos demais, o humor tornava-se um componente central da crítica. Então, na edição no ${ }^{\circ} 129$, de 16 de junho de 1836, assim eram definidos os religiosos: "Frades: Homens que se vestiam pela cabeça, como as mulheres. Foram utilíssimos quando religiosos" (O ARTILHEIRO, 1836u). Seu correspondente feminino: "Freiras: Coitadas, se enganadas!" (O ARTILHEIRO, 1836v). Frades deveriam limitar-se ao seu ofício, sem imiscuir-se em assuntos mundanos (a política, por exemplo). Dessa formulação, podese depreender que, para além do anedótico, havia um objetivo de esclarecimento acerca das posições e funções sociais.

Analisando a evolução do riso, Alberti (1999, p. 160) sustenta que, a partir do final do século XVIII, e no decorrer do XIX, ele ingressa no terreno do entendimento, isto é, passa a ser visto como "instrumento de alargamento do saber" (e a intenção pedagógica de certos verbetes aqui citados parece corroborar essa apreciação); e seria um processo não linear, uma vez que ainda persistiriam temas "resguardados da ridicularização", como: Deus, a religião, a verdade e a virtude. Se esses elementos são, de certa forma, escarnecidos pelo Artilheiro, é precisamente porque havia uma presunção de corrigir comportamentos pela denúncia. Além do mais, a sátira se dirigia, preferencialmente, não à religião idealizada, mas a uma "falsa" religião, assim como a "falsa" virtude é que seria passível de ridículo.

A ironia sarcástica também se voltava contra o centro do poder político e religioso do catolicismo. O que escrevia na edição $\mathrm{n}^{\circ} 282$, de 21 de dezembro de 1836, sobre o Estado pontifical: "Vaticano: Forja de Bulas, e Excomunhões!" (O ARTILHEIRO, 1836af). Essa definição é compreensível, para além do objetivo de fazer rir, em virtude dos conflitos que os Estados nacionais em formação, Portugal inclusive, travavam com o poder papal em relação a vários temas. Um dos mais importantes era a discussão sobre a autonomia que a Igreja tradicionalmente mantivera frente a temas como educação, controle ideológico e moral etc., elementos que, neste período, o Estado buscava abarcar. O verbete "Vaticano" é um híbrido de comentário religioso e político, e nos remete ao que talvez fosse o objetivo principal do dicionário de O Artilheiro, a crítica política e social.

\section{Política e sociedade}

Quando afirmamos considerar o jornal relativamente conservador, devemos lembrar que se tratava de um conservadorismo nos costumes, associado a um liberalismo moderado 
(centrista, poderíamos afirmar com uma boa dose de anacronismo) na política. Isto é, colocava-se distante do republicanismo bem como da monarquia absolutista. Era monárquico constitucional. Isso permitia que se tecessem considerações agudas sobre a situação social, tanto em relação à rigidez hierárquica típica de antigo regime quanto à desigualdade que o advento do capitalismo provocava. Exemplo do primeiro caso: "Avós: Utensílios de aparato para muitos indivíduos. $\$$ Gabar-se de seus Avós, é ir buscar nas raízes o fruto, que deve estar nos ramos da árvore. $\S \hat{E}$ o orgulho de quem não tem outra coisa"; e do segundo, sobre o poder do dinheiro e da financeirização: "Banco: Espécie d'Alquimia, que muda tiras de papel em ouro", conforme mostra a edição $\mathrm{n}^{\mathrm{o}}$ 15, 20 de janeiro de 1836 (O ARTILHEIRO, 1836e).

Como se atingiria a nobiliarquia nos tempos atuais? $\mathrm{O}$ redator respondia, na edição $\mathrm{n}^{\circ} 84$, de 18 de abril de 1836, com novo verbete cáustico: "Enobrecer: Ter muito dinheiro" (O ARTILHEIRO, $1836 \mathrm{~m})$. Talvez, a bem da verdade, tal referência não se limitasse à sua atualidade, pois havia algumas coisasque não mudavam: "Cavalo: Animal que poupa aos pobres o levar às costas os ricos, e poderosos, e puxar pelas carruagens" (O ARTILHEIRO, 1836i). Frente a uma percepção da sociedade tão negativa, embora não desprovida de realismo, a condição de igualitarismo social só poderia estar reservada a um local: "Cemitério: República de verdadeira igualdade" (O ARTILHEIRO, 1836i).

Se o humor, sobretudo aquele veiculado pela imprensa, atinge seu objetivo quando, além de fazer rir, incomoda alguns verbetes do periódico são emblemáticos. No exemplo a seguir, a crítica social tocava em um ponto sensível: o das relações raciais. Então, surgia uma definição cortante: "Eva: Mulher feliz, que não teve Sogra. Dela descendem os brancos, e gente de bem; os pretos e os pobres, duvida-se!!!” (O ARTILHEIRO, 1836q).

As injustiças e os absurdos percebidos no plano social eram responsabilidade da ação política, daí que esta, evidentemente, era muito criticamente satirizada, tanto a de nível local quanto a internacional. O redator promovia, como já foi inferido, uma inversão de ordem: primeiramente, pensava no comentário a ser feito; depois ele era associado a algum termo a ser definido. Por exemplo, a definição do vocábulo "bonachão": "Sobrenome dos Reis de quem nada se pode dizer” (O ARTILHEIRO, 1836f). Uma palavra absolutamente inócua, que não teria outra razão de comparecer no seu léxico a não ser pela sua capacidade de referenciar a crítica à monarquia e sua necessidade de louvação.

Tal recurso é mais bem compreendido considerando que a argumentação que pensa $e$ descreve esse novo horizonte, mais liberal, nessa rede de significados difusos, depende

[...] en muy alto grado de lassituaciones pragmáticas de su enunciación y de las intenciones de los actores. Salta a la vista que, en tales usospolíticos del vocabulario, la función referencial de los términos es relativamente secundaria: el afáne valuativo, performativo y movilizador desborda en la mayoría de los casos al simple interés descriptivo. Las palabras, en política, no se usan tanto para denotar o para señalar determinados objetos, cuanto para persuadir, defender, incitar, ordenar, apoyar, atacar, condenar, zaherir, prohibir, estigmatizar, $y$ asi sucesivamente. (SEBASTIÁN, 2013, p. 14).

Persuadir, mas também estigmatizar, sobretudo pelo deboche. Sob este mote, o dicionário do $O$ Artilheiro emitia juízos relacionados fundamentalmente à política local mesclando apreciações irônicas sobre acontecimentos muito próximos com elementos que apontavam para conceitos e noções já consagrados, mas sempre debatidos. Um termo da "moda" de então: "Regeneração: É destruir, com presunção de fazer melhor. E depois [...]" (O ARTILHEIRO, 1836ad). Em momentos de crise institucional, basicamente provocadas por disputas dinásticas, tais como as que Portugal enfrentava naqueles anos, muitas vezes o governo era exercido por juntas provisórias. E, na visão da edição n ${ }^{\circ} 158$ de $O$ Artilheiro, de 22 de julho de 1836, aparece: "Junta: Ajuntamento de Homens, e de Bois! É preciso tomar muito sentido para que não haja engano neste objeto" (O ARTILHEIRO, $1836 w)$. 
Porém, a visão negativa se estendia para a essência da atividade, extrapolando a consideração sobre ações individuais. Assim, a política era, por definição, marcada pelo engodo e pelo interesse. Exemplos: "Ambiguidade: Ciência de Diplomacia. $₫ \mathrm{O}$ mais necessário ingrediente dos Tratados entre as Nações - das Leis do Poder absoluto - das Notas Diplomáticas - dos Processos - das Sentenças dos Juízes etc. etc", trecho retirado da edição $n^{\circ}$ 9, em 13 de janeiro de 1836 (O ARTILHEIRO, 1836c); "Diplomático: Impostor privilegiado, pago para espiar, intrigar, e enganar o Governo, junto a quem reside: e que depois é premiado na proporção de sua deficiência em honra, e boa fé", citado em 18 de março de 1836, na edição nº 62 (O ARTILHEIRO, 18361).

Os problemas da política, contudo, teriam origem nas convicções arraigadas das pessoas. Para tecer um comentário sobre isso, o redator lançava mão de outra expressão recorrente na imprensa do período, usada na edição $\mathrm{n}^{\circ} 99$, de 6 de maio de 1836, sempre como acusação: "Espírito de partido: Espécie de vitríolo mental, que guardamos para atirar com ele aos outros, e que entretanto vai irritando, corroendo, envenenando o nosso mesmo espírito" (O ARTILHEIRO, 1836p). O aferrar-se às ideias estabelecidas, ao que parece, prejudicaria um debate mais aberto, diríamos, "democrático"? A indagação assume relevância quando nos deparamos com mais um verbete, de uma ambiguidade que desafia a interpretação: "Grécia: País onde mais, e maiores extravagâncias se praticaram antigamente em Política, e Moral" (O ARTILHEIRO, 1836x). A referência à moral dos antigos gregos pode ser lida como uma piada bastante óbvia. Mas, quanto às "extravagâncias" da política, o redator poderia tanto estar lançando uma farpa irônica aos excessos do debate parlamentar quanto à ausência de democracia. A relação com o verbete anterior ("espírito de partido") permite tal elucubração, para uma questão irresoluta. A ambiguidade era outra faceta interessante do dicionário, embora talvez suas definições pudessem parecer menos ambíguas para o leitor daqueles dias.

Entretanto, quando se tratava de defender o regime de sua preferência, inegavelmente o monárquico, era mais direto, sem deixar de mandar recados. Por exemplo, na definição de "Xadrez":

Jogo, que parece inventado para os Reis aprenderem a arte de governar. Ali se lhes recorda, que, se não estiverem sempre rodeados da grande massa dos seus súditos, estão em contínuo risco de levarem mate. Debalde se farão rodear de Torres, Bispos, Patrícios e Cavalheiros: em lhes faltando os Peões, está El Rei perdido. (O ARTILHEIRO, 1836af).

E a maneira de rodear-se da massa dos súditos seria pelo respeito ao regramento constitucional, tema do momento, em Portugal e em vários países. Quanto a esse aspecto da política contemporânea, o significado de "Constituição" seria: "A melhor é aquela que se observa. $\$$ Chapéu de sol dos Corcundas, que eles abrem quando chove, e que fecham quando faz bom tempo", conforme a edição no 40 , de 22 de fevereiro de 1836 (O ARTILHEIRO, 1836k). Percebe-se, no segundo "sentido", uma estocada contra os conservadores, sublinhando o alinhamento do periódico ao liberalismo moderado.

Em termos de política internacional, a questão brasileira ainda estava bastante presente em Portugal. Desse modo, surgia a definição de "Brasil: É um filho que sendo maior de 25 anos, casando, tendo descendência, e bens de seu, se viu obrigado a ir viver debaixo de outro teto, e fundar outra família" (O ARTILHEIRO, 1836f). Ou, no mesmo sentido, "Colônia: Espécie de Gatinho, que custa a criar, e depois arranha" (O ARTILHEIRO, 1836j). Ou seja, tais escritos repercutem aspectos da crise do esfacelamento, então ainda em curso, do antigo império, cujo ápice fora a independência do Brasil.

Os verbetes que tratavam de política demonstram, no seu conjunto, que, mesmo persistindo em seu estilo galhofeiro, este era relativamente contido, quando expunham princípios caros ao(s) redator(es). O humor revestia-se de certa seriedade, em uma combinação de graça com gravidade pedagógica e corretiva. Afinal, havia, por um lado, que estabelecer limites que garantissem uma mínima credibilidade. E, de outra parte, é 
necessário recordar que a folha não nascera para fazer humor, mas política. E aquele estava a serviço desta. Como lembra Elias Palti (2004), a atividade jornalística de então deve ser entendida como instrumento de intervenção prática, inscrita em uma lógica estratégica da política do período, na qual o periodismo surgiu como um modo de discutir e, ao mesmo tempo, de fazer política. Essa característica também infundiu uma nova consciência a respeito do "aspecto performático da palavra", no sentido de sua criatividade (PALTI, 2004, p. 180). Criatividade que, espera-se que reste demonstrado, não faltou à pena de $O$ Artilheiro.

\section{Considerações finais: o humor como arma}

Os exemplos da argumentação de $O$ Artilheiro nos permitem algumas reflexões acerca da ação dos periódicos das primeiras décadas do século XIX, especialmente no que tange à utilização dos recursos retóricos do humor, da sátira, do sarcasmo, do ridículo, aqui tomados sem preocupações teóricas quanto a suas especificidades.

Se fazer rir não era um objetivo precípuo, um fim, era um meio valioso para atingir um público mais amplo com seu discurso político, visto que:

Aquele que procura fazer rir utiliza conscientemente meios visando a um fim, e muitas vezes esse fim não é o riso; o riso é apenas uma transição. [...] Todos os tipos de ironia e de zombaria visam a um objetivo que se situa além do riso. Essa finalidade é mais reveladora das mentalidades do que o riso em si mesmo. (MINOIS, 2003, p. 528).

E para fazer rir é necessário saber rir de si mesmo, pois ridicularizar e brincar com a própria credibilidade era, além do mais, um recurso retórico para captar a simpatia do leitor e "apresentar-se", em relação ao seu estilo livre. A autoironia era uma característica notável, bem como a sátira com a cultura letrada em geral.

Outro aspecto a destacar era a misantropia, a misoginia e certo conservadorismo quanto aos costumes em geral. O redator parecia, pelos exemplos, estar lamentando um passado perdido, ainda não corrompido, no qual o homem era portador de virtudes e a mulher sabia o seu lugar. Sinal de um início de mudança cultural? Seria avançar demasiado, mas determinadas conjunturas permitem o desempenho de novos papéis. Além disso, nesse tema ainda havia um fundo de crítica moral, o que demonstrava as pretensões pedagógicas, que mesmo as folhas menos "sérias" compartilhavam com toda a imprensa do período.

Havia um léxico político muito recorrente nos debates da época, com base em alguns conceitoschave popularizados a partir da Revolução Francesa (KOSELLECK, 2006), mas principalmente ativados depois das guerras de independência e dos subsequentes processos de constituição dos estados americanos, o que também afetou grandemente a Europa. As inquietações acerca de "novidades" (no sentido de seus novos usos) como constituição, regeneração, espírito de partido, entre muitas outras, eram manifestas em Portugal, às voltas com mudanças de gabinetes que alternavam políticas mais ou menos liberais, mas sempre debatendo enfaticamente essas questões e outras correlatas.

Estava em disputa, em Portugal e em grande parte do mundo ocidental, a maneira pela qual se estruturaria e conduziria o Estado em tempos de modificações profundas, advindas da reformulação social, política e econômica forçada pela ascensão da burguesia e da disseminação do capitalismo industrial. Nesse contexto, temas específicos como regime de governo, organização militar, sistema tributário, entre inúmeros outros, agregavamse a questões mais amplas como a religião ou, surpreendentemente e de forma velada, o papel da mulher na sociedade em transformação.

Isso nos permite refletir acerca das permanências e novidades, nos verbetes e suas definições, presentes no campo da linguagem compartilhada, no sentido do contextualismo linguístico, procurando perceber nuances de uma terminologia que, usada de novas maneiras, como resultado de novas experiências e da abertura de novas perspectivas, dão origem a novos problemas e possibilidades (POCOCK, 2003). 
As palavras, acerca de qualquer assunto, servem a muitos objetivos, e os exemplos aqui apresentados salientaram suas funções persuasivas, mas, principalmente, condenatórias e estigmatizantes. Funções nas quais o humor, a ironia, a sátira, o sarcasmo, o deboche, enfim, assumem papel importante; afinal, segundo Sebastián (2013, p. 7): "[...] los historiadores del mundo moderno $y$ contemporâneo deberían prestar mucha más atención a algunos componentes fundamentales de lo político, como son los conceptos, metáforas, símbolos y mitos", pois tais elementos destacam um aspecto substancial, que é a dimensão emocional do político. E essa dimensão, que parte do emocional do próprio redator e joga com as emoções dos leitores, foi permanentemente considerada e ativada pelo $O$ Artilheiro das letras, utilizando o humor como arma. A leitura de seu perspicaz "dicionário" projeta uma luz interessante para uma aproximação ao entendimento da sociedade lusitana de então e, sobretudo, incide na percepção da riqueza dos usos da linguagem que procurava não somente descrever essa sociedade mas também agir sobre ela.

\section{Notas}

1 Era impresso na Imprensa de Gandra \& Filhos. A redação não possui autoria confirmada. O número de páginas e mesmo o tamanho da folha variou durante o período de publicação, mas sempre sem grandes novidades gráficas. Ostentava como epígrafe versos de Filinto Elísio: "Aqui vão troando/Os ecos das Bombas/ Que estouram nas trombas/Dos Rinocerontes".

$2 \mathrm{Na}$ esteira da Revolução Liberal do Porto (1820), o país entrou em um período de disputa pelo poder. Entre vários eventos significativos, vivenciou um golpe de Estado absolutista, com D. Miguel (1828), seguido de uma guerra civil que culminou com a derrota do absolutismo e com a aclamação de Maria II, rainha constitucional. A vitória liberal e o exercício parlamentar fomentaram de maneira decisiva a atividade jornalística e de crítica política.

3 Ao publicar o seu dicionário, O Artilheiro acompanhava uma longa tradição, já presente na cultura ocidental desde a disseminação da imprensa. A reunião de palavras, expressões e ditos com objetivos burlescos e/ou críticos já era bastante comum. Em 1771, por exemplo, o marquês de Bièvres escreve o Almanaque dos trocadilhos, e em 1782, na Inglaterra, surge uma Coleção de epitáfios sérios, brincalhões, satíricos e burlescos (MINOIS, 2003, p. 429-430). A moda dos dicionários satíricos permaneceu, e um dos mais famosos, mas já da segunda metade do século XIX (cuja redação iniciou provavelmente em torno de 1850), foi o de Flaubert (2007).

4 As citações do periódico $O$ Artilheiro tiveram a grafia das palavras atualizada, sem outras alterações do texto. Doravante as citações diretas do jornal que foram mencionadas serão referenciadas apenas identificando o número da edição e a data, sem mencionar a página, por se tratar de documentos impressos sem paginação.

\section{Referências}

ALBERTI, V. O riso e o risível na história do pensamento. Rio de Janeiro: Zahar/FGV, 1999.

BERGSON, H. O riso: ensaio sobre a significação do cômico. Rio de Janeiro: Guanabara, [s. d.].

DARNTON, R. Introdução. In: DARNTON, R.; ROCHE, D. (Org.). A revolução impressa: a imprensa na França, 1775-1800. São Paulo: Edusp, 1996. p. 15-19.

FLAUBERT, G. Dicionário das idéias feitas. Tradução de Cristina Murachco. São Paulo: Nova Alexandria, 2007.

KOSELLECK, R. Uma história dos conceitos: problemas teóricos e práticos. Estudos Históricos, Rio de Janeiro, v. 5, n. 10, p. 134-146, 1992.

Futuro passado. Contribuição à semântica dos tempos históricos. Rio de Janeiro: Contraponto: Ed. PUC-Rio, 2006.

LUSTOSA, I. Insultos impressos: a guerra dos jornalistas na Independência (1821-1823). São Paulo: Cia das Letras, 2000.

MINOIS, G. História do riso e do escárnio. São Paulo: Editora UNESP, 2003.

O ARTILHEIRO. Porto, n. 7, 11 jan. 1836a. Porto, n. 8, 12 jan. 1836 b. . Porto, n. 9, 13 jan. 1836c. Porto, n. 11, 15 jan. 1836 d. Porto, n. 15, 20 jan. 1836 e. 
. Porto, n. 16, 21 jan. $1836 f$.

Porto, n. 23, 30 jan. 1836g.

Porto, n. 26, 4 fev. 1836h.

Porto, n. 27, 5 fev. $1836 i$

Porto, n. 35, 15 fev. 1836j

Porto, n. 40, 22 fev. 1836k.

Porto, n. 62, 18 mar. 18361.

Porto, n. 84, 18 abr. $1836 \mathrm{~m}$.

Porto, n. 87, 21 abr. 1836n.

Porto, n. 92, 27 abr. 1836o.

Porto, n. 99, 6 maio 1836p.

Porto, n. 112, 25 maio 1836q.

Porto, n. 116, 30 maio 1836r.

Porto, n 117, de 31 maio 1836s.

Porto, n. 125, 11 jun. $1836 t$.

Porto, n. 129, 16 jun. 1836u.

Porto, n. 132, 20 jun. 1836v.

Porto, n. 135, 23 jun. 1836x.

Porto, n. 136, 25 jun. $1836 y$.

Porto, n. 158, 22 jul. 1836w.
Porto, n. 193, 5 set. $1836 z$.

Porto, n. 211, 27 set. 1836aa.

Porto, n. 246, 8 nov. 1836ab.

Porto, n. 247, 9 nov.1836ac.

Porto, n. 257, 21 nov. 1836ad.

Porto, n. 264, de 29 nov.1836ae.

Porto, n. 282, 21 dez. 1836af.

PALTI, E. Los diarios y el sistema político mexicano en tiempos de la República restaurada (18671876). In: ALONSO, P. (Comp.). Construcciones impresas: panfletos, diarios y revistas en la formación de los Estados nacionales en América Latina, 1820-1920. México: Fondo de Cultura Económica, 2004, p. 167-182

POCOCK, J. G. A. Linguagens do ideário político. São Paulo: USP, 2003.

SEBASTIÁN, J. F. Conceptos y metáforas en la política moderna. Algunas propuestas para una nueva historia político-intelectual. In: CANAL, J.; MORENO LUZÓN, J. (Ed.). Historia cultural de la política contemporánea. Madrid: Centro de Estudios Políticos y Constitucionales, 2013. p. 7-23. Disponível em: <http://www.javierfsebastian.com/ wp-web/wp-content/uploads/2013/06/Conceptos$\mathrm{y}$-metaforas-en-la-politica-moderna.pdf $>$. Acesso em: 1 dez. 2015. 